\section{Federations and republics}

SIR - Switzerland is not a good example of federal dissolution (Nature 373, 89; 1995) and did not lose Jura to France. Rather, 69.9 per cent of the Swiss electorate having voted in favour, a new canton, Jura, was established inside the Swiss Confederation on 1 January 1979.

Your mention of Jura is nonetheless timely, and President Boris Yeltsin could if he wished still turn the Chechenia quagmire to his democratic advantage. All he needs to do is read a little history. The 'Jura question' goes back well before the period (late 1850s) when the Chechens were being conquered by Russia.

The Swiss Confederation, which has expanded steadily in the past 700 years, is very different from the Russian model. One grew by plebiscite and the putting of heads together, the other by invasion and the bashing of heads together. The former has lasted and matured on the basis of the powerfully attractive concept of selfdetermination, whereas dogma has turned the latter into "the carcass of a failed empire" (The Economist 334, 23; 1995).

There were four quite separate motives for the Chechenia intervention: politicians believed that secession could only sabotage their efforts to breathe new life into an old dream; hard-line strategists were determined to protect the oil pipeline between Baku and Novorossiisk; army commanders wished to give their conscripts something to do; and the Russian man-in-the-street felt that it was time to curtail the deadly activities of hired Chechen gangsters. But it all went wrong.

To the nomenklatura, who have been busy saying, 'You see, democracy doesn't work', Yeltsin can now retort, 'You see, tanks don't work; let us have a referendum'. And the tiny Republic of Chechenia, supported by the Russian electorate, could take its place proudly inside the new federation - as did little Jura, when it seceded peacefully from Berne, not so long ago.

\section{A. L. T. McCammon \\ Tägernstrasse 20 , \\ 8127 Forch, Switzerland}

SIR - When Flashman, in Flashman and the Angel of the Lord (by George Macdonald Fraser), asked Lincoln why it had been all right for the 13 states to secede from the British Empire in 1776, but wrong for the South to want to secede from the Union in 1861, Lincoln replied, "What had right to do with it? The first succeeded and the second failed." A fictional account that embodies an historical truth. History is largely about winners as of course is science.

\section{John Galloway}

54 Windmill Drive,

Croxley Green, Hertfordshire WD3 3FE, UK
SIR - In a discussion of the implications, for science, of the Republican majority in the 104th Congress, Colin Macilwain writes (Nature 373, 5-6; 1995) about "the US Constitution, which was drawn up by Virginian landowners. ..". One expects better than such historical inaccuracy from Nature. The Constitutional Convention met in Philadelphia from 25 May 1787 (the first day when a quorum of seven states was assembled) until 17 September, at which time, of the 55 Framers, 41 were present, all but three of whom put their names to the Constitution. All 13 states except Rhode Island had sent delegates. Virginia sent seven, only some of them landowners.

The two committees most responsible for the actual writing of the Constitution were the committee of detail (one Virginian, Randolph, no landowner) and the committee of style (one Virginian, Madison, a man of such modest means that he had to be supported at the time by his father and friends). The consensus embodied in the final instrument was hammered out in discussions among the delegates during the hot summer of 1787 .

So the statement that the Constitution "was drawn up by Virginian landowners" is a flagrant misstatement of the facts. The facts are readily available (see for example 1787 - The Grand Convention, Clinton Rossiter, 1966).

\section{Emanuel Epstein}

Department of Land, Air and Water Resources,

Soils and Biogeochemistry Program, University of California,

Davis, California 95616, USA

\section{Randomized trials}

SIR - In offering caution about a phrase about non-randomized trials in our Commentary ${ }^{1}$, Peto and Collins ${ }^{2}$ risk misleading readers. We said and continue to believe that "New statistical approaches often allow results approximating those from trials to be extracted from routine clinical data". Our comment was addressed to two situations that often confront clinicians. In the first, action is required and the results of randomized trials are not available. In such circumstances, optimal patient care requires that existing information be used for the best possible decisions. Second, when interventions may be harmful, randomized trials are clearly not acceptable.

An example of the first is the close correspondence of the (non-randomized) Duke coronary artery disease database and the results of subsequent randomized trials of coronary artery bypass grafting $^{3-5}$. Other methods for observational studies can be improved to yield results that are more similar to those of randomized trials ${ }^{6}$

We strongly agree, of course, that randomized trials are to be preferred when they are feasible and ethical. But alternative sources of information should not be dismissed out of hand. Physicians and policy-makers must often rely on non-randomized observations until the results of definitive trials are available. Finally, occasional interventions may have such a substantial impact that the moderate bias introduced by nonrandomized methods can be tolerated. We should therefore continue to encourage the development of methods to use detailed routine clinical data, which should not be confused with the demographic information in an administrative database.

\section{Lee Goldman}

Howard Hiatt

Brigham and Women's Hospital,

75 Francis Street,

Boston,

Massachusetts 02115, USA

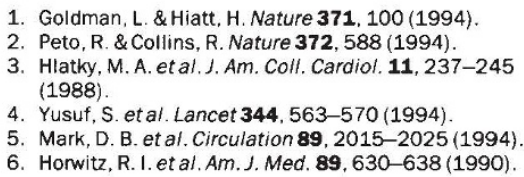

\section{Popular science}

SIR - One can only applaud and encourage the collaboration between Nature and Le Monde (Nature 373, 2; 1995). Popularization of scientific research is an valuable and important part of scientific work.

But I believe the flame of interest in the layman must be kindled at a far earlier stage than the average age of the readership of the broadsheets. As the product of the French schooling system and subsequent British university training, I fully agree with the comment that French people retain intellectual interest far beyond that of many nations. This I believe is as much due to their educational philosophy as to any other national trait, and it is symptomatic of that approach that a French newspaper has joined Nature in this venture. French education is based on instilling a sense of pride and importance in the pursuit of knowledge. An individual is believed to thrive on more than practical or physical skills. This interest subsequently remains throughout the individual's life.

Britain might benefit from considering this approach because it would, I believe, become far more receptive and sympathetic to the benefits and importance of science.

\section{A. S. K. Dzlk-Jurasz}

11 Carlton Park Avenue,

London SW20 8BJ, UK

NATURE · VOL 373 - 2 FEBRUARY 1995 